\title{
GREEK FAMILY POLICY FROM A COMPARATIVE PERSPECTIVE ${ }^{1}$
}

\author{
Theodoros N. Papadopoulos ${ }^{2}$
}

\begin{abstract}
Introduction $^{3}$
In Greece, as in most Southern European countries, the key welfare provider is the 'family'. ${ }^{4}$ This chapter explores the role of Greek family policy in sustaining this welfare arrangement. The policy components under investigation include arrangements for child care provision; arrangements for maternity, paternity and parental leave; and the value of the total "package" of transfers to families with children in the form of benefits, tax allowances and various subsidies. The results point to the rudimentary character of the Greek family policy as one of the major factors in reproducing the primacy of the 'family' in welfare provision in Greece. Furthermore, they raise questions about the type of gender relationships within and outside the household that the Greek family policy sustains and, eventually, legitimizes.
\end{abstract}

\section{The predominance of the nuclear family in Greece}

A comparison of family composition in the European Union countries reveals the strong attachment of Greeks to the nuclear family form (Papadopoulos 1996: 172). Greece has the highest percentages of couples with children (89.1 per cent) and married couples with two children (42.3 per cent) in Europe. Not surprisingly, it has also the lowest percentage of lone parent families (10.9 per cent) and one of the lowest percentages of lone mothers with one child (5.4 per cent). However, Greece appears closer to the European average for larger families. Couples with three children constitute 10.7 per cent of the total number of families with children, a percentage close to the ones of Belgium (10.6), Italy (10.9) and the UK (10.9). In addition, Greece is amongst the countries with the lowest percentages of families consisting of couples with four or more children.

The centrality of family as a social institution in Greece is clearly manifested in ideological and symbolic terms in the social values and attitudes held by Greek men and women. In comparison to other Europeans, Greeks appear as the most strongly attached to, and supportive of, the institution of the family (CEC 1993). An overwhelming 99.4 per cent of the Greek respondents placed the family as their top priority on the value scale - the highest percentage in the European Union. However, despite the strong ideological attachment to the institution of the family, a series of ideological changes have taken place in respect of the social roles within families. They relate to a series of

\footnotetext{
${ }^{1}$ Copyright note: This chapter is published as Papadopoulos T.N. (1998), Greek Family Policy from a Comparative Perspective, in Drew E., Emerek R. and Mahon E. (eds.). Women, Work and the family in Europe, London: Routledge, pp. 47-57. This online version of the paper may be cited or briefly quoted in line with the usual academic conventions. You may also download it for your own personal use. This paper must not be published elsewhere (e.g. mailing lists, bulletin boards etc.) without the author's explicit permission. Please note that (a) if you copy this paper you must include this copyright note; (b) this paper or any translation of it must not be used for commercial purposes or gain in any way; (c) you should observe the conventions of academic citation.

${ }^{2}$ Lecturer in Social Policy, University of Bath

${ }^{3}$ This chapter is based on empirical evidence collected for an earlier work (Papadopoulos 1996). The author would like to acknowledge the financial support of the Onassis Foundation for this project and the editors of this book for their comments and suggestions. Special thanks go to Emma Carmel for her invaluable help and remarkable patience.

${ }^{4}$ In this study the concept of 'family' refers both to a social institution and a social process and includes material and ideological aspects. A fundamental assumption is that family policies affect the extent to which particular notions of the 'family' are reproduced as resources (material and symbolic) and, consequently, certain family types are encouraged or discouraged in a given society.
} 
socio-political and economic changes, often defined as the "modernization" that has occurred in Greece since the early 1960s. Directly or indirectly these changes have influenced the structure of families in Greece, especially their size and the gender roles within and outside the household. During the late 1970s and through the 1980s what has been clearly observed was a transition from an extended family system to a nuclear family system . This transition was accompanied by a shift from traditional to more egalitarian gender roles within the household, a modest but steady increase in women's participation in the labour market and a gradual adoption of individualist values (Lambiri-Dimaki, 1983; Doumanis, 1983; Kouvertaris and Dobratz, 1987; Georgas, 1989).

Current demographic trends (see chapter one) provide further evidence of the strong attachment to the "family" and the shift towards smaller family sizes. Greece continues to have one of the lowest divorce rates and the lowest percentage of births outside marriage in Europe, 0.7 and 2.7 per cent respectively (Eurostat 1994b: 4), despite the fact that the Greek Orthodox church exercises far less moral pressure on issues like divorce and abortion compared to the Roman Catholic church. Low levels of lone parenthood are attributed to the stigma attached to it, access to private, and relatively unrestricted, abortion and the limited welfare support for lone parents. This lack of support reflects and reproduces certain attitudes and social practices with regard to the institution of marriage and the nuclear family.

The shift towards smaller families is evident in the trend towards lower fertility rates. In the period 1977-1993 the total fertility rate has fallen from 2.27 to 1.38 children per woman, one of the lowest in Europe (Papadopoulos 1996). The decrease was more dramatic during the 1980s which registered the largest single decrease in Europe during this period (European Commission 1995: 39). However, the causes behind this spectacular falling cannot be solely attributed to changes in social values. When Dretakis (1994) investigated the changes in the levels of income of couples in the period between 1981-1991 he found that while the average income of a couple (without children) lost 16.4 per cent of its purchasing power, couples increasingly tended to delay having children. During the same period, the average income of couples with one child lost 7 per cent of its purchasing power a fact which, according to Dretakis, explains why couples tended to postpone having subsequent children or stopped having children altogether. Dretakis concluded that there was an urgent need to take serious measures to alleviate economic inequalities amongst Greek families and most importantly to increase the level of child allowance.

\section{Greek Family Policy in a Comparative Perspective}

In this section, the Greek family policy is compared to the policies of other European Union countries. The aim is to seek patterns of similarity and difference, especially among the countries that constitute the periphery of the European Union. In particular, the aim is to examine to what extent the latter countries go in helping parents to reconcile work and family life and, in the case of the Greek family policy, how this policy sustains the predominant role of the nuclear family in welfare provision in Greece.

\footnotetext{
5 'Modernization' refers to: the shift from an economy based on agriculture to an economy based on services and (to a lesser extent) industry; the expansion of Greek statism and the intensification of "intra-middle-class conflicts for access to the state machinery" (Petmesidou, 1991: 40); the phenomena of rapid urbanization and migration; the cultural and economic impact of tourism; the increase in accessibility to higher education; the increase in women's labour force participation (small though it was); and last, but by no means least, changes in family legislation which preceded entry into the European Community.
} 


\section{Child care}

Table 4.1 presents a comparison of the regulations and levels of child care provision in the EU member states. Ten countries have the 6th year as the age of compulsory schooling, a clear case of convergence. However, in child care provision for children up to three years of age a clear case of divergence emerges. Two clusters of countries are evident: Austria, FRG (formerly West Germany), Greece, Ireland, Luxembourg, Spain and the UK which have minimum provision, for only two to three percent of children in this age group. Italy and Netherlands offer higher levels of coverage, 6 and 8 per cent respectively, but they are still low in comparison to the rest of the countries. The second cluster consists of countries with levels of childcare provision well above 20 per cent: Finland ( 21 per cent) and France (23 per cent) are at the margins, followed by Belgium and Sweden with 30 and 33 per cent respectively. Denmark and the former GDR (East Germany) offer the highest levels of coverage in the EU (50 per cent).

Table 4.1: Regulations and levels of child care provision in the European Union

\begin{tabular}{lllll}
\hline Countries & $\begin{array}{l}\text { Reference } \\
\text { year }\end{array}$ & $\begin{array}{l}\text { Age of compulsory } \\
\text { schooling }\end{array}$ & $\begin{array}{l}\text { Child care for } \\
\text { children } 0-3 \\
\%\end{array}$ & $\begin{array}{l}\text { Child care for } \\
\text { children 3-6 } \\
\%\end{array}$ \\
\hline Austria & 1994 & 6 & 3 & 75 \\
Belgium & 1993 & 6 & 30 & 95 \\
Denmark & 1994 & 7 & 50 & 79 \\
Finland & 1994 & 7 & 21 & 43 \\
France & 1993 & 6 & 23 & 99 \\
Germany (West) & 1990 & 6 & 2 & 78 \\
Germany (East) & 1993 & 6 & 50 & 100 \\
Greece & 1993 & 6 & 3 & 64 \\
Ireland & 1993 & 6 & 2 & 58 \\
Italy & 1991 & 6 & 6 & 91 \\
Luxembourg & 1989 & 6 & 2 & $75-60$ \\
Netherlands & 1993 & 5 & 8 & 48 \\
Portugal & 1993 & 6 & 12 & 64 \\
Spain & 1993 & 6 & $(2)$ & 72 \\
Sweden & 1994 & 7 & 33 & 60 \\
UK & 1993 & 5 & 2 & \\
\hline
\end{tabular}

Sources: Ruxton S. (1996); Data for Luxembourg from Glasner (1992: 83).

Notes: * Places in childcare or children attending, as a percentage of children in age group. For information on the method of measurements see Ruxton (1996: 156).

The pattern changes when one examines the child care provision for children between three and six years of age, that is pre-primary school care. Provision is significantly higher and, although there is still diversity, a degree of convergence is evident. At the low end of the provision continuum there is Finland (43 per cent) and Portugal (48 per cent) followed by Ireland ( 58 per cent), Luxembourg (5560 per cent) and the UK (60 percent). Spain and Greece (with 64 per cent), are closer to the average. At the high end of the continuum there is the Netherlands ( 71 per cent), Sweden ( 72 per cent), 
Austria (75 per cent), FRG (formerly West Germany) (78 per cent) and Denmark (79 per cent). Italy, Belgium, France and the former GDR (East Germany) are at the top, all providing more than 90 per cent. Overall, Denmark, Belgium, France and Sweden are the countries that provide the most comprehensive child care provision in the European Union. In the eastern part of Germany the levels of child care remain high but, due to the economic constraints of unification, it is reasonable to expect a reduction in provision. In the periphery of Europe (Ireland, Spain, Portugal, Italy and Greece) the level of childcare for children up to three years of age is very low. In pre-primary school care (3-6 years of age) provision is better - but still at modest levels - with the exemptions of Portugal (low) and Italy (very high).

\section{Leave provisions}

Another key element in examining the extent to which the peripheral welfare states support parents in reconciling working and family life, concerns the arrangements for maternity, paternity and parental leave provisions. Table 4.2 provides a summary of these arrangements in the fifteen EU countries.

Table 4.2: Regulations for leave provisions in the European Union

\begin{tabular}{|c|c|c|c|c|c|}
\hline \multirow[t]{2}{*}{ Countries } & \multicolumn{2}{|c|}{ Maternity leave (paid) } & \multicolumn{2}{|c|}{ Paternity leave (paid) } & \multirow[t]{2}{*}{ Parental leave } \\
\hline & weeks & $\mathrm{RR}^{\mathrm{a}}$ & days & $\mathrm{RR}^{\mathrm{a}}$ & \\
\hline Austria & 16 & 100 & - & - & 2 years \\
\hline Belgium & 15 & $82-75$ & 3 & 100 & 6-12 months \\
\hline Denmark & 18 & flat rate & 10 & flat rate & 6-12 months \\
\hline Finland & 17.5 & $66-45$ & $6-12$ & $66-45$ & up to 3 years \\
\hline France & $16-26$ & 84 & 3 & & 3 years \\
\hline Germany & 14 & 100 & - & - & 3 years \\
\hline Greece & 16 & 100 & - & - & 3.5 months $^{\mathrm{b}}$ \\
\hline Ireland & 14 & 70 & - & - & - \\
\hline Italy & 22 & 80 & - & - & 6 months \\
\hline Luxembourg & 16 & 100 & - & - & - \\
\hline Netherlands & 16 & 100 & - & - & 4 years $^{c}$ \\
\hline Portugal & 18 & 100 & - & - & 6-24 months \\
\hline Spain & 16 & 75 & 2 & 100 & $12-36$ months \\
\hline Sweden & $12-24$ & 90 & 10 & 80 & 18 months \\
\hline UK & 14 & flat rate & - & - & - \\
\hline
\end{tabular}

Sources: Ruxton S. (1996); Ditch et al (1996)

Notes: ${ }^{\mathrm{a}}$ Replacement Rate of normal earnings during the period of leave.

${ }^{\mathrm{b}}$ For lone parents the period is six months. It applies only to those employed by companies with more than 50 employees.

${ }^{\mathrm{c}}$ Parent entitled to work reduced hours - not transferable

The arrangements for paid maternity leave in Greece follow the European average, 16 weeks with 100 per cent income replacement. The arrangements in the countries of European periphery vary. In Ireland paid maternity leave is given for 14 weeks on 70 per cent income replacement, in Spain for 16 weeks on 75 per cent, in Portugal for 18 weeks on 100 per cent and in Italy for 22 weeks on 80 per cent RR. However, Greece pays the lowest maternity benefits compared to the other EU 
countries (Eurostat 1993: 6) far below Spain, Portugal and Italy which also pay low maternity benefits. Ireland is exceptional in this case having one of the highest maternity benefits in the European Union.

Furthermore, with the exception of Spain, no other country of the European periphery provides a right to paternity leave. As far as parental leave is concerned arrangements vary considerably. While in most of the EU member states statutory entitlement to parental leave is paid, this is not the case in Greece, Portugal and Spain. Greece offers the shortest period of parental leave in Europe, although there are special provisions for lone parents (six months). However, the fact that parental leave is offered only to those employed by companies with more than 50 employees excludes the largest part of the labour force which is employed in small enterprises. Indeed, it is generally accepted that take up is very low.

\section{The Greek child support package}

The third most important element of a family policy is income transfers to families. Table 4.3 sets out a comparative table of the main forms of these transfers, that is family benefits (income and nonincome related) and tax allowances, and the criteria used in twelve European Union member states. A method increasingly used in evaluating the resources aspect of family policy is to 'translate' this data into policy outputs and compare them across countries. Thus, in order to evaluate the total Greek child support income package, the results of a series of comparative studies are used. The first of this studies used a standardized methodology in order to simulate the net disposable income that a number of 'model' families would theoretically receive in fifteen countries in 1992 (Bradshaw et al, 1993). The net disposable income of different family types was calculated by taking into account: the earnings from employment, family benefits (both non-income and income-related), tax allowances, social security contributions, health costs, housing costs (rent) and benefits as well as education costs and subsidies.

Overall, southern European countries and Ireland provided the least generous packages across all family types, including lone parents. Greece, in particular, ranks last in the overall evaluation of generosity and, with regards to lone parents, second from the bottom, above Spain. Moreover, further elaboration of the data (Bradshaw et al. 1993; Papadopoulos 1996) in terms of the welfare system's vertical and horizontal redistributive efforts - from wealthier households to poorer and from childless couples or individuals to families with children respectively - revealed that the Greek system was among the least redistributive. ${ }^{6}$

\footnotetext{
${ }^{6}$ Given the lack of any serious redistributive effort built in the Greek tax and benefit policies and the fact that the level of inequality in income distribution in Greece is the highest in Europe (Lane and Ersson 1987: 83) one may question, as Petmesidou (1990: 39) does, the existence of a welfare state in Greece.
} 
Table 4.3: Family policies in the European Union (12)

\begin{tabular}{|c|c|c|c|c|c|c|c|}
\hline Countries & $\begin{array}{l}\text { Non income- } \\
\text { related } \\
\text { family benefits }\end{array}$ & Vary according to & Taxable & $\begin{array}{l}\text { Income-related } \\
\text { family benefits }\end{array}$ & Vary according to & Tax allowances & Vary according to \\
\hline Belgium & yes & $\begin{array}{l}\text { number of children } \\
\text { age of child employment } \\
\text { status }\end{array}$ & no & no & $\mathrm{n} / \mathrm{a}$ & yes & $\begin{array}{l}\text { number of children } \\
\text { age of child } \\
\text { some tax relief for child care } \\
\text { expenditure }\end{array}$ \\
\hline Denmark & yes & $\begin{array}{l}\text { age of child } \\
\text { lone parents }\end{array}$ & no & no & $\mathrm{n} / \mathrm{a}$ & no & $\mathrm{n} / \mathrm{a}$ \\
\hline France & yes & $\begin{array}{l}\text { number of children age } \\
\text { of child } \\
\text { lone parents } \\
\text { mother's employment } \\
\text { status } \\
\text { (various schemes) }\end{array}$ & no & yes & $\begin{array}{l}\text { number of children } \\
\text { age of child } \\
\text { lone parents } \\
\text { mother's employment } \\
\text { status } \\
\text { (various schemes) }\end{array}$ & yes & number of children \\
\hline Germany & yes & $\begin{array}{l}\text { number of children } \\
\text { age of child }\end{array}$ & no & $\begin{array}{l}\text { no } \\
\text { but Sozialhilfe } \\
\text { pays (means } \\
\text { tested benefit) }\end{array}$ & $\mathrm{n} / \mathrm{a}$ & $\begin{array}{l}\text { yes, fixed amounts } \\
\text { for each child } \\
\text { special tax } \\
\text { allowances for lone } \\
\text { parents. }\end{array}$ & age of child \\
\hline Greece & yes & $\begin{array}{l}\text { number of children } \\
\text { age of child }\end{array}$ & $\begin{array}{l}\text { yes, some } \\
\text { types of } \\
\text { benefits }\end{array}$ & yes & $\begin{array}{l}\text { number of children } \\
\text { lone parents }\end{array}$ & yes & number of dependants \\
\hline Ireland & yes & $\begin{array}{l}\text { number of children } \\
\text { no additions for lone } \\
\text { parents }\end{array}$ & no & yes & number of children & $\begin{array}{l}\text { no tax allowances } \\
\text { but tax exemption } \\
\text { limit is increased } \\
\text { accordingly }\end{array}$ & $\begin{array}{l}\text { marital status } \\
\text { number of children }\end{array}$ \\
\hline
\end{tabular}


Table 4.3: Family policies in the European Union (12) - continued

\begin{tabular}{|c|c|c|c|c|c|c|c|}
\hline Countries & $\begin{array}{l}\text { Non income- } \\
\text { related } \\
\text { family benefits }\end{array}$ & Vary according to & Taxable & $\begin{array}{l}\text { Income-related } \\
\text { family benefits }\end{array}$ & Vary according to & Tax allowances & Vary according to \\
\hline Italy & no & $\mathrm{n} / \mathrm{a}$ & $\mathrm{n} / \mathrm{a}$ & yes & $\begin{array}{l}\text { number of persons } \\
\text { in the household } \\
\text { special allowance } \\
\text { for lone parents }\end{array}$ & yes & $\begin{array}{l}\text { number of children } \\
\text { some school costs } \\
\text { are deducted from } \\
\text { taxable income }\end{array}$ \\
\hline Luxembourg & yes & $\begin{array}{l}\text { number of children } \\
\text { age of child }\end{array}$ & no & no & $\mathrm{n} / \mathrm{a}$ & yes & marital status \\
\hline The Netherlands & yes & $\begin{array}{l}\text { number of children } \\
\text { age of child }\end{array}$ & no & no & $\mathrm{n} / \mathrm{a}$ & $\begin{array}{l}\text { no, but lone parents } \\
\text { receive a tax free } \\
\text { allowance }\end{array}$ & age of child \\
\hline Portugal & yes & $\begin{array}{l}\text { number of children } \\
\text { age of child }\end{array}$ & no & yes & (various schemes) & yes, tax deduction & $\begin{array}{l}\text { marital status } \\
\text { number of earners } \\
\text { number of } \\
\text { dependants }\end{array}$ \\
\hline Spain & no & $\mathrm{n} / \mathrm{a}$ & $\mathrm{n} / \mathrm{a}$ & yes & number of children & $\begin{array}{l}\text { yes, tax deduction } \\
\text { also pre-school care } \\
\text { costs can be } \\
\text { deducted from } \\
\text { taxable income }\end{array}$ & $\begin{array}{l}\text { couples can be } \\
\text { taxed separately }\end{array}$ \\
\hline UK & yes & $\begin{array}{l}\text { number of children lone } \\
\text { parents }\end{array}$ & no & yes & age of child & $\begin{array}{l}\text { no but lone parents } \\
\text { can receive a } \\
\text { personal allowance }\end{array}$ & $\mathrm{n} / \mathrm{a}$ \\
\hline
\end{tabular}

Sources: Compiled from national reports (Bradshaw et al 1993: 103-30; Eurostat 1993b: 86-212) 
When the same methodology was applied again, simulating net disposable income for 1994, researchers arrived at similar conclusions. A comparative study on the impact of tax and benefit systems on the financial incentives facing lone mothers in twenty countries (Bradshaw et al. 1996) and the report of the European Observatory on National Family Policies (Ditch et al. 1995) have confirmed that in Greece and the rest of the countries in the European periphery the levels of child support are particularly low.

Finally, a recent comparative study of social assistance in the OECD countries (Eardley et al. 1996) and a study of support for the unemployed and their families in the European Union (Papadopoulos 1997) re-confirmed the low levels of Greek welfare support not only towards families with children but also towards families at risk of poverty.

To summarize, compared to other European and Western countries Greece ranks very low in terms of child care provision (especially for children up to the age of three), parental leave arrangements, levels of maternity benefits and welfare support for families with children. In the light of these findings, increasing public dissatisfaction with the Greek family policy is clearly comprehensible. A Eurobarometer survey (CEC 1993: 119) recorded 36.9 per cent of Greek respondents mentioning the level of child allowance as one of the most important issues on which the government should act to make life easier for families. As an indicator of dissatisfaction with the welfare state support for children, this is the highest in the European Union and far beyond the EU average level of dissatisfaction (22.5 per cent).

\section{Family policy and familism in Greece}

Despite the strong attachment of Greeks to the "family", welfare state support for families is almost non-existent. This inconsistency is illustrative of the socio-economic role that the nuclear family performs in Greece in providing welfare for its members, in both affective and material terms. Thus, the Greek family policy, through its inaction, implicitly nurtures and reproduces the ideological assumption that the family is the main provider of welfare in society. This process is defined as "Greek familism".

Primarily, the Greek nuclear family unit - similar to other southern European 'families' - is "still largely operating as a social clearing house, mediating the difficult relationships between a variegated labour market and equally variegated income maintenance systems" (Ferrera: 1996, 21). In addition, it is perceived by its members as the main vehicle for social mobility (Tsoukalas 1987: 268). This belief is embodied in the social practices of almost all social classes through a system of attitudes, visions and expectations which produce a special kind of solidarity within the family collective. One could argue that the Greek nuclear family functions internally as a co-operative while competing with other families in a society dominated by the idea of social mobility. Solidarity remains firmly within the private sphere, as an inter-generational responsibility towards the family unit $^{7}$ (5). In this context, the development of notions of social responsibility or social solidarity, essential for the creation and functioning of a civil society, encounter enormous obstacles. Thus, the possibility of creating a sustainable ideological base for expanding the residual welfare state in Greece is limited.

\footnotetext{
${ }^{7}$ According to CEC (1994: 39) 69 per cent of young people in Greece obtain their job through their family, the highest percentage in Europe
} 


\section{The gender aspects of Greek familism}

Greek familism fosters solidarity within the family. However, this is by no means the only social relationship that it reproduces. If Greek familism is analyzed in terms of gender, a pattern of dependency and power relationships among the members of Greek families emerges. The inaction of Greek family policy results in reinforcing the role of women as the sole carers of children by nurturing, reproducing and legitimizing their dependency on men (see chapter two). Hence, despite the legislative rhetoric, the Greek family remains firmly patriarchal in its structure. Nonetheless, one has to emphasize that patriarchy is still confined to the private domain and a shift towards public patriarchal relationships, as defined by Walby (1990), has not yet occurred. Like in Ireland (Mahon, 1994) and the rest of the southern European countries, the residual family policy of the Greek welfare state reproduces the structure of private patriarchal relationships.

Since it is assumed that the family will bear the burden of child care, and given the modest arrangements in maternity leave and the low levels of maternity benefits, Greek women find it particularly hard to participate in the labour market. A comparative examination of the Greek female activity rate reveals that Greece continues to have one of the lowest female activity rates in Europe, 34.2 per cent compared to an average of 44 per cent for the EU (Eurostat 1994: 20). Hence, the Greek welfare system fits all the criteria for qualifying as a strong male breadwinner regime (Lewis 1992).

\section{Conclusion}

The differences between national family policies in the European Union are often attributed to the different patterns of welfare state development in member states. National family policies are formulated and implemented within diverse institutional settings which, due to their history, allow for a variety of responses to what appears to be similar sets of challenges. Hence, successful social policy responses to new challenges are directly linked to the flexibility and adaptability of these institutional structures.

In this context, developing welfare states, such as those at the periphery of the European Union, stand at a crossroads as they face two contradicting sets of priorities. On the one hand, there is the economic dimension: the erosion of the state's economic sovereignty coupled with the priority of meeting the criteria regarding participation in the EMU and the economic restructuring that competition in European and global markets brings about. On the other hand, there is a increasing demand to expand the role of the state in the welfare mix, as the traditional forms of welfare provision find themselves under enormous pressure precisely because the economic restructuring creates new patterns of employment insecurity and social exclusion (Petmesidou 1996). In addition, there is a pressing need to deal with the complex dynamics of women's participation rates, gender equality and fertility. These create a set of dilemmas significantly different from those that more developed welfare states of the European Union face, namely the 'rolling back' of their welfare states. In the majority of countries in the European periphery, and certainly in Greece, there is no dilemma on this issue simply because there is no significant welfare state to 'roll back'. On the contrary, the dilemma is what will be the role of the state, now that traditional forms of welfare provision are severely challenged. Only the future will show if the institutional structures of the countries in the periphery of Europe will provide adequate responses to these fundamental challenges. 


\section{References}

Bradshaw, J., Ditch, J., Holmes, H., Whiteford, P.(1993) Support for Children: A Comparison of Arrangements in Fifteen Countries, London: HMSO.

Commission of the European Communities (1993) Europeans and the Family: Results of an Opinion Survey, Report prepared by N. Malpas and P. Lambert, Brussels: Eurobarometer 39.

Commission of the European Communities, (1994) The Major Issues of European Demography, Joint Report by Independent Experts, Brussels.

Ditch , J., Barnes, H., Bradshaw, J., Commaille, J. and Eardley, T. (1996) A Synthesis of National Family Policies, European Observatory on Family Policies, University of York.

Doumanis, M. (1983) Mothering in Greece: From Collectivism to Individualism, New York: Academic Press.

Dretakis, M. (1994) 'The Reduction in Income resulted in a Reduction in the Birth Rate', Eleftherotypia (Greek daily), 21 September, Athens (in Greek).

Eurostat, (1993) Digest of Statistics on Social Protection in Europe, Volume 4: Family, Luxembourg: Office for Official Publications of the European Communities.

Eurostat, (1994a) Labour Force Survey 1992: Results, Luxembourg: Office for Official Publications of the European Communities.

Eurostat, (1994b) Rapid Reports: The Population of the European Economic Area on 1 January 1994, No. 4, Luxembourg: Office for Official Publications of the European Communities.

Ferrera, M. (1996) 'The "Southern European Model” of Welfare in Social Europe', Journal of European Social Policy, 6, 1: 17-37.

Georgas, J. (1989) 'Changing Family Values in Greece', Journal of Cross-Cultural Psychology, 20, 1: 80-91, Western Washington University.

Glasner, A. (1992) 'Gender and Europe: Cultural and Structural Impediments to Change' in J. Bailey (ed.), Social Europe, London: Longman.

Kouvertaris, Y. and Dobratz, B. (1987) A Profile of Modern Greece: In Search of Identity, Oxford: Clarendon Press.

Lambiri-Dimaki, J. (1983) Social Stratification in Greece: 1962-1982, Athens: Sakkoulas (in Greek).

Lane, J. E. and Ersson, S.O. (1987) Politics and Society in Western Europe, London: Sage.

Lewis J. (1992) 'Gender and the Development of Welfare Regimes', Journal of European Social Policy, 2, 3: 31-48. 
Mahon, E. (1994) ‘Ireland: A Private Patriarchy’, Environment and Planning , 26: 1277-1296.

Papadopoulos, T. (1996) “"Family”, State and Social Policy for Children in Greece' in J. Brannen and M. O'Brien (eds.), Children in Families: Research and Policy, London: Falmer Press.

Papadopoulos, T. (1997) Welfare Support for the Unemployed: A Comparative Analysis of Social Policy Responses to Unemployment in the European Union Countries, D.Phil. Thesis, University of York.

Petmezidou M. (1996) 'Social Protection in Southern Europe: Trends and Prospects', Journal of Area Studies (special issue on southern Europe).

Petmezidou, M. (1991) 'Statism, Social Policy and the Middle Classes in Greece', Journal of European Social Policy, 1, 1: 31-48.

Tsoukalas, K. (1987) State, Society and Work in Postwar Greece, Athens: Themelio (in Greek).

Walby, S. (1990) Theorizing Patriarchy, Oxford: Basil Blackwell. 